\title{
Preferences of Teaching Methods and Techniques in Mathematics with Reasons ${ }^{i}$
}

\author{
Menderes Ünal \\ Faculty of Education, Ahi Evran University, Kirsehir, Turkey
}

Copyright $(2017$ by authors, all rights reserved. Authors agree that this article remains permanently open access under the terms of the Creative Commons Attribution License 4.0 International License

\begin{abstract}
In this descriptive study, the goal was to determine teachers' preferred pedagogical methods and techniques in mathematics. Qualitative research methods were employed, primarily case studies. 40 teachers were randomly chosen from various secondary schools in Kursehir during the 2015-2016 educational terms, and data were gathered via semi-structured interviews. While analyzing the data, a categorical descriptive analysis technique was employed in which participants' opinions were divided into categories and sub-categories, and quotations were included to ensure opinions were reflected accurately. Results of these interviews showed that teachers preferred techniques such as "Question and Answer" and "Demonstration," that offered relative ease of use. Techniques such as "Scenario" and "Case Study" had fallen out of favor, as they required greater preparation and use of educational materials.
\end{abstract}

Keywords Teaching Techniques, Teaching Methods, Mathematics, Reasons

\section{Introduction}

Educational systems consist of many elements, including students, teachers, curriculum, administrators, specialists, technology, physical and financial resources. However, teachers are the essential element, since quality of the education mostly depends on the quality and competence of teachers $[37,2]$.

Teachers have many roles, from planning classroom activities, to instructing, disciplining, motivating and guiding students. Teachers are also expected to both use teaching techniques effectively and to have modern management skills in classroom environments [15] in order to establish learning that can be defined as permanent changes in behavior. Those factors which most impact students' learning and performance are not only teachers' attitudes, choice of methodology, and the content of curriculum, but also students' socioeconomic background, behavior, and personal characteristics [32, 38, 22, 33, 14, 28, 27, 12]. Effective teaching, therefore, must place equal emphasis on teacher, student, environment, curriculum and other factors [42].

Teaching mathematics is related to more than one variable as well as to other disciplines. The primary goal of efficient mathematical teaching is to transfer mathematical knowledge in a way that allows students to adapt to new situations and knowledge [29]. In history, mathematics has been used to supply fundamental needs of societies; as mathematical knowledge progressed, so did technology, with many new scientific branches emerging [11].

Mathematics curriculums have aimed to provide students with the fundamental mathematical skills needed for further education, including understand mathematical concepts; developing their own mathematical thinking and problem-solving processes; using these skills both in real life and in the classroom; systematically improving their skills, and behaving responsibly [25].

The chief aim of mathematics education extends beyond motivating students to learn the basic mathematics that they will need in school; rather, it is to convince them (in the hope that they will continue to learn beyond the classroom) to adapt to the mathematical challenges that their future lives will present [36]. Mathematics, as an academic course and as a mode of thought, begins in students' primary education and continues throughout their lifetime learning; moreover, there is a strong relationship between mathematical success and academic success in other courses. Changes and adaptations in other disciplines deeply affect the teaching-learning process in mathematics [3].

Teachers' preferences and opinions regarding pedagogical techniques in mathematics courses are important, because they may reveal their ability to address the needs of students at different learning levels. The study began with a self-evaluation of the teachers' strengths and weaknesses regarding their teaching preferences. As teachers develop their teaching skills, they may help students integrate their mathematical knowledge with other activities, and find out what works best for their personalities and curriculum [33]. 
The following principles may provide guidance for effective classroom practices in supporting mathematics teaching. First, it is recommended that teachers build on children's natural interest in mathematics, and on their intuitive and informal mathematical knowledge. They should encourage inquiry and exploration to foster problem-solving and mathematical reasoning [52]. Second, teachers are expected to use both formal academic lessons and everyday activities as natural vehicles for developing children's mathematical knowledge. Providing a mathematically rich environment and incorporating the language of mathematics throughout the school day could be effective. Third, teachers are also advised to use literature to introduce mathematical concepts, and then reinforce them with hands-on activities. Finally, it is recommended that teachers establish partnerships with parents and other caregivers in order to support children's mathematical development [34, 47].

Mathematics was chosen as an object of study because it can be described as a common tool and language used to define mental schemas throughout the world. Individuals who lack basic mathematical skills may face difficulties in school and social life; overcoming such difficulties requires the establishment of an effective learning environment. Reaching this goal depends on the employment of effective pedagogical methods; it is therefore essential to investigate different teaching methods - problem solving, inquiry based teaching, discovery, games, lecturing, and case studies, among others - and to draw attention to effective teaching and learning processes.

\section{Research Method}

This descriptive study aimed to identify various teaching techniques used in mathematics classes, and to understand why teachers prefer them. Descriptive models describe past or present situations as it was or as it is characteristically. These methods could be described as survey methods in which situations, events, objects, circumstances, institutions, groups and various areas have been tried to describe in their contexts as well $[18,16]$.

Data were collected for this study using case studies, a qualitative research method. According to Yildırım and Simsek [44], case studies enable researchers to prioritize questions of "what" and "why," by examining individual cases in detail. Qualitative research can therefore be described as "....research in which qualitative data-collecting techniques such as observation, interview and document analysis are used, and a qualitative process carried out to reveal perceptions and cases in their natural environment as exact and integrated." Yin [45] defines the case study as a relative research model, used when case borders are uncertain and there are enough data sources in real life borders.

The study's central subjects are teachers, represented here by a focus group composed of Mathematics teachers at schools of Kirsehir Directorate of National Education.
Interviews were conducted with 40 teachers, who were selected for the study by a random sampling method. The study group was constituted of 14 (35\%) females and 26 $(35 \%)$ male teachers.

\section{Data Collection}

Data were collected using semi-structured interview, one of the qualitative data-collecting techniques. Interviews are one of the most frequently used data collection tools in qualitative research. An interview is an interaction process based on asking and answering questions designed to provide insight on a predetermined and specific topic. Patton [31] also explains the interview's purpose as stepping in a person's inner world and understanding his perspective.

In the interview form of this research, common teaching techniques (Demonstrate and Practice, Question-Answer, Problem Solving, Lecturing, Games, Discovery, Describing, Cooperative, Case Study and Scenario) which were proposed by recent studies $[6,48,49,50,54]$ were listed and teachers were asked to indicate how often they used each technique in their courses. They were also asked to explain the reasons why they preferred or eschewed those teaching techniques.

In quantitative research, validity depends on the evaluator's objectivity [20]. To increase this study's reliability, followings were employed:

a) The researcher clearly defined his position, as simply the interpreter and not a participant.

b) Data resources were defined clearly, as participants' were quoted in the comments to ensure accurate representation of their opinions.

c) Social environment and process was clarified, as data were collected through asking participants to explain their preferences by complete prompt "I prefer this technique/ method because ..." and teachers were asked to rate a five Likert type question showing how often they use each technique.

d) Conceptual framework was expressed directly. Volunteer Mathematics teachers from the schools in Kırşehir were given about a week to generate their reasons.

e) As a result of inductive analysis procedure, 11 major conceptual themes were identified.

f) In establishing the inter-rater reliability rate, a specialist at the faculty was asked to sort the reasons into the 11 categories, and the level of agreement between the colleague and the researcher was $92 \%$. The colleague placed 28 reasons (hands-on activities, practical activities, inevitable in mathematics, etc). under categories different from that of the researcher (i.e., Reliability $=$ Agreement $/$ Agreement + Disagreement $X$ $100=323 / 323+28 \times 100=92 \%)[21,26]$.

\section{Data Analysis}

Data were analyzed using the descriptive analysis 
approach, one of the qualitative research data-analysis techniques. In descriptive analysis, participants' opinions are quoted to ensure they are accurately reflected $[44,26,31]$. The steps in the qualitative data analysis process are as follows:

a) First, data from document analysis and interviews were transferred to PC using Office programs. Texts were examined in detail, and categories and terms were determined. Second, data were separated into meaningful categories in order to identify distinct concepts.

b) In the coding and elimination stage, all the reasons were simply coded $(n=37)$ such as "Sampling", "Active Participation", "Reinforcing" etc.). Codes were also established in order to categorize and classify study group members such as "1E" for the first male participant; " $2 \mathrm{~K}$ " for the second female participant.

c) In the compilation stage, expressions and similar reasons for each teaching technique were compiled by going through all the answers.

d) In the sorting and categorization stage, each of the reason generated by 40 teachers was analyzed to characterize its category $(n=11)$ such as, Demonstrate and Practice, Question-Answer, Problem Solving, Lecturing, Games, Discovery, Describing, Cooperative, Case Study and Scenario.

e) Frequencies of various opinions were expressed as percentages, and the mean calculated as a metric of how often the teachers employed particular teaching techniques.

f) After identifying common codes and categories, teachers' opinions were expressed in "Sample Statement Parts" within the tables. Finally, analogous comments and results were interpreted according to the study's aim.

\section{Findings}

Techniques preferred by Mathematics teachers were presented by percentage (\%) and frequency (f) to form a meaningful whole. Findings were interpreted according to literature after giving the concepts related to the techniques (Table 1).

Table 1. Total Concepts of Teaching Techniques and Methods with Reasons

\section{TEACHING TECHNIQUES \& METHODS}

\begin{tabular}{|c|c|c|c|c|c|c|c|c|c|c|c|c|}
\hline $\begin{array}{l}\text { REASONS FOR } \\
\text { PREFERENCE }\end{array}$ & $\begin{array}{c}\text { Demo } \\
\text { and } \\
\text { Practice }\end{array}$ & $\begin{array}{l}\text { Question. } \\
\text { Answer }\end{array}$ & $\begin{array}{l}\text { Problem } \\
\text { Solve }\end{array}$ & $\begin{array}{l}\text { Putting } \\
\text { Rule }\end{array}$ & Lecture & Games & Discover & Describe & Cooperate & $\begin{array}{l}\text { Case } \\
\text { study }\end{array}$ & Scenario & $\sum$ \\
\hline Active Participation & 2 & 6 & 2 & & & & 1 & & 1 & 1 & & 13 \\
\hline Sampling & 4 & & 4 & & & & & & & & & 8 \\
\hline Inevitable in Geometry & 6 & & & 1 & & & & & & & & 7 \\
\hline Practical activities & 4 & 2 & 4 & 2 & & & & 2 & & 1 & & 15 \\
\hline Hands on Activities & 5 & & & & & 1 & 5 & & & 2 & 2 & 15 \\
\hline Learning by watching & 4 & & & & & & & & & & & 4 \\
\hline Save time & 2 & & 1 & & 6 & & & & & & & 9 \\
\hline Permanent learning & 1 & & 4 & & & 2 & 6 & & 1 & & 3 & 17 \\
\hline Motivate students & 1 & 2 & & & & & 5 & & 2 & 1 & & 11 \\
\hline For General Review & & 3 & 1 & 1 & 2 & & & 1 & & & & 8 \\
\hline Awareness & & 2 & & & & & & & & 2 & & 4 \\
\hline Evaluate & & 6 & & & & & 1 & & & & & 7 \\
\hline Socializing of students & & 3 & & & & 3 & & & 2 & & & 8 \\
\hline Effective method & & 3 & & & & & 1 & & & & & 4 \\
\hline Develop thinking skills & & & 6 & & & & 2 & & & & & 8 \\
\hline Basic of mathematics & & & 5 & 5 & & & & & & & & 10 \\
\hline Good communication & & & 1 & & & & & & 4 & & & 5 \\
\hline Inevitable in Math & & 1 & & 4 & 7 & & & 7 & & & & 19 \\
\hline Simplify learning & 1 & & & 1 & 1 & 3 & 3 & 2 & 4 & 4 & 3 & 22 \\
\hline Discipline learning & & 1 & & 1 & & & & & & & & 2 \\
\hline New learning & & & & & 3 & & & & & & & 3 \\
\hline Introducing the course & & & & & 4 & & & 5 & & & & 9 \\
\hline Make enjoyable & & & & & & 7 & & & 3 & & 3 & 13 \\
\hline Updating & & & & & & 2 & & & & 4 & 3 & 9 \\
\hline
\end{tabular}


Table 1. Total Concepts of Teaching Techniques and Methods with Reasons (Continued)

\begin{tabular}{|c|c|c|c|c|c|c|c|c|c|c|c|c|}
\hline \multirow[b]{2}{*}{$\begin{array}{l}\text { REASONS FOR } \\
\text { PREFERENCE }\end{array}$} & \multicolumn{12}{|c|}{ TEACHING TECHNIQUES \& METHODS } \\
\hline & $\begin{array}{l}\text { Demo and } \\
\text { Practice }\end{array}$ & $\begin{array}{l}\text { Question. } \\
\text { Answer }\end{array}$ & $\begin{array}{l}\text { Problem } \\
\text { Solve }\end{array}$ & $\begin{array}{l}\text { Putting } \\
\text { Rule }\end{array}$ & Lecture & Games & Discover & Describe & Cooperate & $\begin{array}{l}\text { Case } \\
\text { study }\end{array}$ & Scenario & $\sum$ \\
\hline Concretization & & & & & & & & 1 & & 2 & 1 & 4 \\
\hline Feeling of help/ share & & & & & & & & & 11 & & & 11 \\
\hline Get rid of monotony & & & & & & 2 & 1 & & 1 & 1 & 1 & 6 \\
\hline NOT contemporary & & & & 3 & & & & & & & & 3 \\
\hline Monotony & & & & & 5 & & & & & & & 5 \\
\hline Temporary Learning & & & & & 2 & & & 2 & & & & 4 \\
\hline Waste of time & & & & & & 2 & 5 & & 1 & 3 & 4 & 15 \\
\hline Overcrowded classes & & & & & & 1 & & & & & & 1 \\
\hline NOT up to student level & & & & & & & 2 & 2 & & & & 4 \\
\hline NOT up to mathematics & & & & & & & 1 & & 1 & 2 & 1 & 5 \\
\hline Lead to memorize & & & & & & & & 3 & & & & 3 \\
\hline$\sum$ & 30 & 36 & 31 & 18 & 33 & 33 & 36 & 27 & 31 & 25 & 23 & 323 \\
\hline
\end{tabular}

As seen in Table 1, there are 323 reasons given by teachers expressing their preferences about 11 teaching techniques. Of these, "Question and Answer" ( $\mathrm{f}=36)$ and "Discovery" $(\mathrm{f}=36)$ were most frequently emphasized and preferred. "Putting Rules ( $\mathrm{f}=18)$ " was the least popular technique. Regarding the reasons for using particular techniques, teachers most frequently cited a technique's ability to "Simplify Learning $(\mathrm{f}=22)$ ", or its consistency with the "Inevitable in Mathematics ( $\mathrm{f}=19)$ " and "Permanent Learning ( $\mathrm{f}=17)$ " categories. Of the reasons given for eschewing particular teaching techniques, five of them-particularly "Discovery Learning," "Scenario" and "Case Study"-were considered a waste of time $(f=15)$, while lecturing was viewed as monotonous.

Table 2. Demonstrate and Practice Technique with Reasons for the Preferences

\section{REASONS FOR THE PREFERENCES IN CATEGORY} $(\mathrm{f}=30 ; \overline{\mathrm{X}}=3,65)$

Inevitable in Geometry(6), Hands on Activities(5), Sampling(4), Fast learning by watching(4), Practical activities(4), Active participation(2), Save time(2), Permanent learning (1), motivate students (1), Simplify learning(1)

\begin{tabular}{l} 
SAMPLE STATEMENTS OF THE TEACHERS \\
\hline 1B: Provides students participation to the courses. \\
7B: Useful in Geometry, especially in the drawing. \\
25E: Useful in using time properly. \\
4B: Helps sampling.
\end{tabular}

As shown in Table 2, the "Demonstrate and Practice" technique was cited by 30 out of 40 teachers as one that they "usually" employed compared to the mean $(3,65)$. This technique was believed to correspond with the inevitable in geometry, allow teachers to employ hands-on activities, provide sampling, and help students learning quickly by watching.

The "demonstrator" or "coach" technique allows teachers to demonstrate their expertise by showing students what they need to know. This teaching style provides teachers with opportunities to incorporate a variety of formats including lectures, multimedia presentations and demonstrations. Although it is well-suited for teaching mathematics, music, physical education, arts and crafts, it is difficult to accommodate students' individual needs in larger classrooms [46].

Table 3. Question-Answer Technique with Reasons for the Preferences

\section{REASONS FOR THE PREFERENCES IN CATEGORY} $(\mathrm{f}=36 ; \overline{\mathrm{X}}=3,65)$

Evaluation (6), Reinforce(6), Active participation(5), Socialize(3), Effective method(3), General review (3), Awareness(2), Motivation(2),

Practical activities(2), Discipline(1), Attract attention(1), Inevitable in Math(1), Draw interest(1).

\section{SAMPLE STATEMENTS OF THE TEACHERS}

4B: Reinforces and accelerates learning.

11B: Provides students take part courses actively, helps to discipline learning, enables students to communicate and discuss with both teachers and peers. Moreover provides self evaluation of students. 38E: Motivates and socializes students.

According to Table 3, the "Question-Answer" technique was emphasized by 36 out of 40 teachers, or "usually" compared to the mean $(3,65)$. This technique was believed to enable students to be evaluated, help teachers to reinforce students, and provide opportunities for socialization. It was viewed as an effective method that provided active participation opportunities for students and general review for teachers. Likewise, Grasha [13] noted that once teachers allowed students to participate in activities, show delegator characteristics, guide discovery, inquiry-based learning and place themselves in an observer role that inspired students by helping them work in tandem toward common goals.

Table 4. Problem Establishing and Solving Technique with Reasons

\section{REASONS FOR THE PREFERENCES IN CATEGORY $(\mathrm{f}=31 ; \overline{\mathrm{X}}=3,45)$}

Develop thinking skill(6), Basic of Mathematics (5), Sampling(4), Practical activities (4), Permanent learning(4), Active participation(2), Reinforcing (2), Save time(1), General Review(1), Good communication(1), Draw interest(1)

\section{SAMPLE STATEMENTS OF THE TEACHERS}

4B: Helps to develop thinking skills, while doing review and reinforcing activities.

9E: To construct and solve a problem provide permanent learning.

10B: Problem solving is the basic concept in mathematics. So I use this technique.

18E: Because of tight schedule and limited time I prefer lecturing and problem solving. First I give sample problem solution and want students to discuss and solve more.

38E: Enriches different thinking skills. 
As seen in Table 4, the technique of "Problem Establishing and Solving" was cited by 31 out of 40 teachers, or "usually" compared to the mean $(3,45)$. This technique was preferred for teaching mathematics because it developed thinking skills, provided practical activities, and encouraged permanent learning. It was also taken as the inevitable in Mathematics, reinforcing students' active participation.

Developing problem solving-skills deserves to be prioritized in curriculum planning, learning concepts, logical operations and mathematical communication. Students should be guided to develop problem-solving skills through interactive activities which are closely tailored to the lesson at hand [23].

Table 5. Putting Rules Technique with Reasons

REASONS FOR THE PREFERENCES IN CATEGORY $(\mathrm{f}=18 ; \overline{\mathrm{X}}=2,90)$

Basic of Mathematics(5), Inevitable in Mathematics (4), NOT keep fit contemporary approaches in learning(3), Practical activities (2), Inevitable in Geometry(1), Generalizing (1), Simplify learning(1), Discipline learning(1).

\section{SAMPLE STATEMENTS OF THE TEACHERS}

4B: I use this technique to generalize subjects at the end. 9E: Rules are the basic of Mathematics

11B: It is sometimes necessary to put rules and want students to do some activities such as memorizing. This seems not contemporary but it works if the subject is complex.

17E: I don't prefer because it is not a modern method.

42E: Learning rules help to learn subjects of the courses

Analyzing Table 5, the technique of "Putting Rules" was cited by 18 of 40 teachers, meaning it is used "sometimes" compared to the mean $(2,90)$. It means that they sometimes preferred this technique while teaching mathematics because this technique was thought to be consistent with the inevitable in Mathematics, helping to generalize, simplify and discipline learning but three contrary ideas emphasized that putting rule was not a contemporary approach in learning. The mean score is comparatively low since this model is teacher-centered and frequently entails lengthy lecture sessions or one-way presentations. Students are expected to take notes or absorb information. This could be acceptable for certain higher-education disciplines and auditorium settings with large groups of students. However, it is a questionable model for teaching because there is little or no interaction with the teacher [47].

Table 6. Lecturing Technique with Reasons for the Preferences of Teachers

\section{REASONS FOR THE PREFERENCES IN CATEGORY}

$$
(\mathrm{f}=33 ; \mathrm{X}=2,70)
$$

Inevitable in Mathematics (7), Save time(6), Monotony (5), Introducing the course(4), Attract attention (3), Passing to the new learning (3), General review(2), Temporary Learning (2), Simplify learning(1).

\section{SAMPLE STATEMENTS OF THE TEACHERS}

\footnotetext{
1B: Because of monotony and being not attractive I don't use.

9E: In this technique, learning is the least permanent

20B: This technique enables to overcome time problem to finish the subjects.

38E: I prefer because introduction part and concept teaching in not possible without lecturing

40E: To attract attention and summarize the subject, I sometimes employ this technique
}

According to Table 6, the technique of "Lecturing" was singled out 33 times by 40 teachers, whose opinion was at "sometimes" level compared to the mean $(2,70)$. It means that they sometimes preferred this technique while teaching mathematics because this technique was thought as in the inevitable in mathematics, saved time; attracted attention, was helpful introducing new subjects and learning. On the other hand 7 different ideas expressing that it brought monotony and caused temporary learning.

Lecturing - in other words, direct instruction-helps students understand the "why" behind their activities. When introducing a new lesson, it's important to emphasize the broader concepts as a whole to ensure comprehension, rather than individual facts, as these can distract from the overall message [46].

Table 7. Game Technique with Reasons for the Preferences of Teachers

\section{REASONS FOR THE PREFERENCES IN CATEGORY} $(\mathrm{f}=33 ; \overline{\mathrm{X}}=2,67)$

Make enjoyable(7), Attract interest(6), Reinforcement(4), Socializing the students(3), Simplify the learning (3), Permanent learning(2), Updating (2), Up to the level of the students(2), Waste of time(2), Hands on Activities (1), Overcrowded classes(1).

\section{SAMPLE STATEMENTS OF THE TEACHERS}

5E: Playing games are not possible because of overcrowded classes.

7B: Provides attract interest and makes enjoyable learning especially late and boring hours

10B: I use very often in practice. $5^{\text {th }}$ and $6^{\text {th }}$ grade children are at the age of game. So this technique is effective to simplify and have good time.

22E: To make enjoyable, attract attentions and help to update students' learning

37B: To reinforce and target hardening, I prefer games

42E: No more time left to play games because of limited duration.

As shown in Table 7, the technique of "Game" was cited 33 times by 40 teachers, whose opinion was at "sometimes" level compared to the mean $(2,67)$. It means that they sometimes preferred this technique while teaching mathematics because this technique made learning enjoyable, attracted interest, reinforced, socialized students and contributed to simplification. Few of the teachers $(\mathrm{f}=3)$ believed games to be a waste of time or impossible to put in practice in crowded classes and not up to the levels of students. Furthermore, learning by game could overcome fear, anxiety and negative attitudes toward mathematics that lead students to failure $([1,41,10]$.

As seen in Table 8, the technique of "Discovery" was cited 36 times by 40 teachers whose opinions were at "sometimes" level compared to the mean $(2,65)$. It means that they sometimes preferred this technique while teaching mathematics because this technique was thought to contribute to permanent learning, enable hands-on activities and motivate students. Moreover, it simplified learning, retained students' attention, and developed thinking skills. However some teachers $(\mathrm{f}=8)$ thought that it was a waste of time and not up to the level of students. 
Table 8. Discovery Technique with Reasons for the Preferences of Teachers

\begin{tabular}{|c|c|}
\hline & $\begin{array}{l}\text { REASONS FOR THE PREFERENCES IN CATEGORY } \\
(\mathrm{f}=36 ; \mathrm{X}=2,65)\end{array}$ \\
\hline & $\begin{array}{l}\text { Permanent learning (6), Hands on Activities (5), Motivate } \\
\text { students(5), Waste of time(5),Simplify learning(3), Attract } \\
\text { attention (3), Develop thinking skills(2), NOT up to student } \\
\text { level(2), Active participation(1), Evaluation(1), Effective } \\
\text { method(1), Get rid of monotony(1), NOT up to mathematics(1). }\end{array}$ \\
\hline & \\
\hline & $\begin{array}{l}\text { 1B: It helps to attract attention of the students } \\
\text { 4B: I use to develop thinking skills of the students and attract } \\
\text { attention } \\
\text { 7B:Once a student discovers, learning becomes permanent } \\
\text { 12E: I DON'T prefer since it is not up to students' readiness } \\
\text { level } \\
\text { 17E: I rarely use because of the time limitation } \\
\text { 26E: This technique enables to take part students in activities } \\
\text { 10B: In our daily live and in our classroom we learn } \\
\text { permanently in the way of discovering. So I put this method in } \\
\text { practice very often. }\end{array}$ \\
\hline
\end{tabular}

Discovery activities promote self-learning and help students develop critical thinking skills and retain knowledge that leads to self-actualization. This technique trains students to ask questions and helps develop skills to find answers and solutions through exploration; it is ideal for teaching science and similar subjects. So, this technique could be recommended to mathematics teachers for employment in the classroom, and outside it as well, where it may help to cement permanent learning [17].

Table 9. Describing Technique with Reasons for the Preferences of Teachers

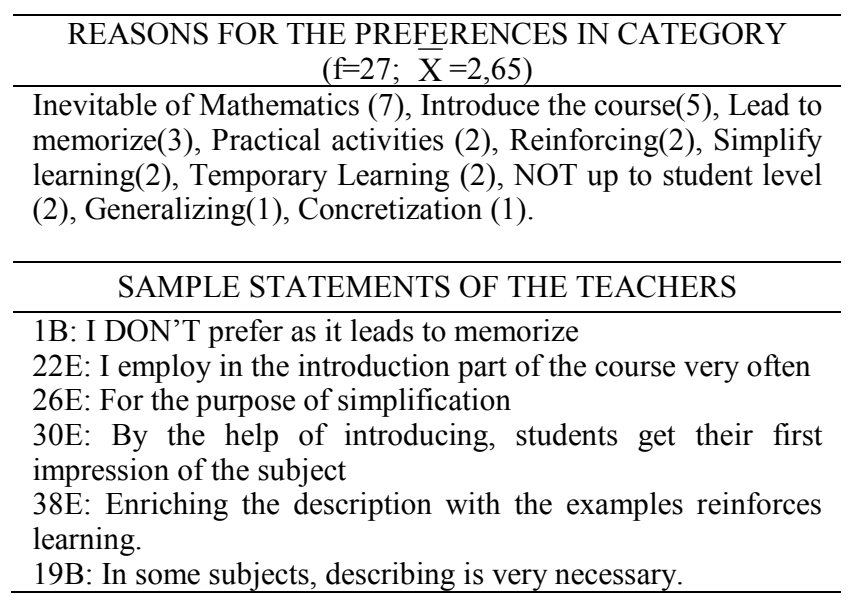

According to Table 9, the technique of "Describing" was cited 27 times by 40 teachers whose opinion is at "sometimes" level compared to the mean $(2,65)$. It means that they sometimes preferred this technique while teaching mathematics because this technique was thought to correspond to the inevitable in mathematics, employed practical activities, was helpful for teachers while introducing the course, reinforced the students and helped to simplify learning. On the other hand, some teachers didn't find this technique useful $(\mathrm{f}=7)$ because it was assumed to be memorizing and caused students to forget their learning easily.
Table 10. Cooperative Learning Technique with Reasons for the Preferences of Teachers

REASONS FOR THE PREFERENCES IN CATEGORY

$$
(\mathrm{f}=31 ; \overline{\mathrm{X}}=2,55)
$$

Feeling of help and share (11), Simplify learning(4), Good communication(4), Make enjoyable(3), Motivate students(2), Socializing(2), Permanent learning(1), Get rid of monotony(1), Active participation(1), Waste of time(1), NOT up to mathematics (1)

SAMPLE STATEMENTS OF THE TEACHERS
9E: Enables to group study
11B: Helping and sharing, some of the daily life skills will be
acquired ; will be motivated together; expressing, listening
skills will be pushed up.
17E: Learning by helping each other
18E: Interaction of the students with peers and teachers
provide permanent learning
20B: For me this technique is not suitable since time
limitations.
21B: Develops communication and social support among
students

Up to Table 10, the technique of "Cooperative Learning" was stated out 31 times by 40 teachers whose opinion was at "Rarely" level considering the mean(2,55). It means that they rarely preferred this technique while teaching mathematics because this technique was thought as to develop feeling of help and share, interaction, good communication and group study. It was also assumed as simplifying and making enjoyable the learning by motivating the students.

With cooperative learning students get the chance to work with one another toward a common goal. These exercises are valuable in their capability to teach students about the values of cooperation and working with others who might be different from themselves. Pairing students with different skill can contribute to the work meaningfully in their own way. Collaboration encourages students to engage in productive dialogue and it can provide an opportunity to foster debate. Deciding between different approaches to satisfy project requirements can help develop students' executive decision-making capabilities and their ability to listen to others' opinions and suggestions [4, 53].

Table 11. Case Study Technique with Reasons for the Preferences of Teachers

\section{REASONS FOR THE PREFERENCES IN CATEGORY}

$$
(\mathrm{f}=25 ; \overline{\mathrm{X}}=2,43)
$$

Update(4), Simplify learning(4), Waste of time(3), NOT up to mathematics (2), Hands on Activities (2), Concretization(2), Awareness(2), Active participation(1), Practical activities (1), Motivation(1), Attract attention(1),Draw interest(1), Get rid of monotony(1).

\section{SAMPLE STATEMENTS OF THE TEACHERS}

1B: Helps students be aware of difference

9E: Sometimes, It needs to concretize the concepts

10B: I DON'T use very often since our subjects are too much and time is limited.

17E: It helps to face and overcome the problems of real life. 26E: For the purpose of concretization, I sometimes employ.

Table 11 showed that the technique of "Case Study" was 
stated out 25 times by 40 teachers whose opinion was at "Rarely" level considering the mean $(2,43)$. It means that they rarely preferred this technique while teaching mathematics because this technique was thought as helping to update, simplifying the learning, employs hand on activities and provides sampling and concretization. However some teachers $(\mathrm{f}=5)$ thought that it was a waste of time and not up to mathematics.

In case study techniques, students often have been given some opportunities to create something on their own, which leads to retention in learning. If a student is more active in different areas, has the greater chance for retention. Hands-on activities are traditionally used in arts, science and math courses. These types of modern activities can be more meaningful and engaging to students than traditional exams, and encourage more creative, independent thinking and awareness [7].

Table 12. Scenario Technique with Reasons for the Preferences

REASONS FOR THE PREFERENCES IN CATEGORY
$(\mathrm{f}=23 ; \overline{\mathrm{X}}=1,95)$

Waste of time(4), Permanent learning(3), updating (3), Simplify(3), Enjoyable learning(3), Hands on Activities (2), Attract attention(2), Concretization (1), Get rid of monotony(1), NOT up to mathematics (1).

\section{SAMPLE STATEMENTS OF THE TEACHERS}

1B:To attract the attention of the students

4B: I prefer this technique to make the course enjoyable

7B: In some complex subjects such as "Permutation\& Combination" this technique helps to concretize and enjoyable.

8E: In many subjects like "possibilities", it enables students to understand easily

9E: By means of this technique, it is possible to get rid of monotony.

Analyzing Table 12, the technique of was stated out 23 times by 40 teachers whose opinion was at "Rarely" level considering the mean $(1,95)$. It means that they rarely preferred this technique while teaching mathematics because this technique was thought as provided permanent learning and concretization, helped to update, simplified learning, employed hand on activities, attracted attention and contributed to get rid of monotony. On the other hand some teachers $(\mathrm{f}=5)$ thought that it was a waste of time and not keep fit mathematics teaching and learning methodology. Teaching Mathematics is a complex process and it needs special attention and planning while putting activities into practice. Otherwise, it will be a failure of teacher and teaching [6].

\section{Discussion}

These findings clearly demonstrate that mathematics teachers mainly preferred techniques requiring less preparation and effort, such as "Question and Answer" and "Demonstration."Techniques requiring greater preparation and materials, such as "Scenario" and "Case study," were less popular. "Putting Rules" was generally not employed by teachers, as they believed it to be incompatible with contemporary approaches to learning. According to Kazelskis [19], study of pedagogical techniques has revealed two different attitudes towards mathematics. Teaching techniques that students prefer improve attitudes, result in greater comfort with academic material, and ultimately increase success. Teaching techniques that students dislike may inspire fear and discomfort, which can be difficult to overcome.

Surprisingly, some techniques-such as Games, Discovery, Case Study and Scenario - were viewed as a waste of time. One possibility is that teachers' favorite teaching techniques were simply those that required less time and preparation. Grasha [13] suggests that it is not easy for teachers to take on a less central role and to empower students. For example, colleagues have told him that "I could never show a video tape or hold a small group discussion in my classes. Such things would take valuable time away from what I have to offer." This could be an excuse for not employing certain techniques in the classroom, but participating students and effective courses have been pioneering as valuable.

Analyzing the reasons for these teachers' preferences, most techniques were valued for the sake of inevitable in mathematics and geometry. It means that they have been using those techniques in their course but they didn't have a clear reason or explanation for their preference. It appears that many of these teaching techniques were employed because of the expectation that they would simplify mathematical subjects.

Teachers rarely mentioned overcrowded classes; this problem was cited only once, as a reason for avoiding the "Game" technique. Likewise, physical environment and materials were not given as either reasons or excuses for avoiding particular techniques. Based on these findings, it appears that Turkish schools were assumed to be well-equipped, with adequate access to technology. In this context, it must be emphasized that, in mathematics classes, learning environment is vitally important as well as teacher and materials [30, 5, 51]. Verschaffel et al. [43], Toptaş [40] and McDonough [24] stated that there is a direct relationship between mathematical thinking, problem solving and physical, social, academic designed learning context.

Students were more confident in cases where they could solve more problems on their own, and see the value of their strategies - this enhanced patience and creativity in problem-solving [39]. Therefore, we conclude that problem solving is one of the basic skills in instruction, and should be prioritized in curriculums of all levels and schools by directorate of national education [24].

Furthermore, many teaching techniques were valued for their tendency to facilitate active participation, hands-on activities, and practical activities; in other words, courses were mostly organized around student-centered activities. It appears that effective mathematical teaching and learning are possible only when aided by activities requiring students' 
active participation.

Corresponding research conducted by Aydın and Doğan [3] has investigated some of the various obstacles or barriers to successful mathematics teaching, arguing that teachers should receive qualitative education, and should use modern pedagogical methods rather than traditional, teacher-centered techniques. Instead of memorizing concepts, knowledge should be constructed in students' minds through questioning and discussion, and through early learning. Information should be made meaningful to students in order to establish permanent learning $[9,41,53]$.

Cotton [8] stated that any approach that relies on a sequence of pre-structured questions and does not provide students with adequate time to explore their own responses. In teaching mathematics, pre-structured questions should allow enough time to organized students' exploration of their own responses to situations. Moreover, such questions must be structured to inspire students' wonder and interest, which enhance participation and self-confidence.

In light of these findings, it is recommended a blended teaching approach, one that balances teachers' personal strengths and interests with students' needs and curricular requirements. Since it achieves the inclusive approach of combining teaching clusters, it enables teachers to tailor their teaching to student needs and subject matter.

In summary, pedagogical policies in mathematics should focus on graduating mathematical thinking students who can use mathematical language and techniques effectively both in and outside of the classroom. Teachers may have individual styles reflecting their distinct personalities and curriculums, but it's crucial that they remain focused on their teaching objectives. It is also recommended that, before teaching classes or working in schools, teachers receive formal training in new pedagogical developments.

\section{REFERENCES}

[1] Alkan, V. (2010).Matematikten nefret ediyorum! Pamukkale Üniversitesi Eğitim Fakültesi Dergisi, 28, 189-199.

[2] Arı, R. \& Saban, A. (2000). Sinıf yönetimi. Konya: MikroDizgi.

[3] Aydın, B. \& Doğan, M. (2012). Matematik öğretimi: Geçmişten günümüze matematik öğretimi önündeki engeller. Batman Üniversitesi Yaşam Bilimleri Dergisi,(1), 2.

[4] Barkley, E. F, Cross, K. P. \& Major, C. H. (2005) Collaborative learning techniques: A Handbook for college faculty. San-Francisco: Jossey-Bass.

[5] Bay, J. M., Beem, J. K., Reys, R. E., Papick, I. \& Barnes, D. E. (1999). Student's reactions to standards-based mathematics curricula: The interplay between curriculum, teachers and students. School Science and Mathematics, (4), 182-188.

[6] Baykul, Y. (2009). İlköğretimde matematik ögrretimi. Pegema Yayıncıl1k, Ankara.
[7] Christensen, C. R. (1981) Teaching by the case method. Boston: Harvard Business School.

[8] Cotton, K. (1989). Classroom questioning. School improvement research series. Northwest Regional Educational Laboratory. Retrieved on 10.09.2016 from http://www.nwrel.org/scpd/sirs/3/cu5.html.

[9] Dereli,M.(2008). Tam sayılar konusunun karikatürlerle ögretiminin ögrencilerin matematik başarllarına ve tutumuna etkisi. Yayımlanmamış yüksek lisans tezi, Marmara Üniversitesi, Eğitim Bilimleri Enstitüsü. İstanbul.

[10] Gierl, M. J. \& Bisanz, J. (1995). Anxieties and attitudes related to math in grades 3 and 6. Journal of Experimental Education, 63 (2), 139-158.

[11] Görgen, İ. \& Tahta, H. (2005): Liselerde matematik öğretimi sürecindeki öğretmen davranışları ile öğrenci beklentilerinin karşılaştırılması. Milli Eğitim Dergisi, 33, 166.

[12] Grant, C. E. (1984). A study of the relationship between secondary mathematics teachers' beliefs about the teaching-learning process and their observed classroom behaviors (conceptions). Dissertation Abstracts International, 46 (4), 919.

[13] Grasha, A. F.(1994). A Matter of style: The Teacher as expert, formal authority, personal model, facilitator and delegator. College Teaching, 42, 142-149: Heldref Publications.

[14] Hopko, D.R, Lejuez C. W., Lepage, J. P., Hopko S.D \& McNeil, D.W. (2003). A Brief behavioral activation treatment for depression. Behavior Modification, Vol. 27 No. 4, 458-469.

[15] Kahyaoğlu, M. and Yangın, S. (2007). İlköğretim öğretmen adaylarının mesleki özyeterliklerine ilişkin görüşleri. Kastamonu Ĕ̌itim Dergisi, 15, 83.

[16] Kaptan, S. (1998). Bilimsel araştırma ve istatistik teknikleri. Ankara: TekışıkOfset.

[17] Kara, Y. \& Özgün-Koca S.A. (2004). Buluş yoluyla öğrenme ve anlamlı öğrenme yaklaşımlarının matematik dersinde uygulanmasi: "İki terimin toplamının karesi" konusu üzerine iki ders planı. Illköğretim online, (3), 1, 2-10.

[18] Karasar, N. (2003). Bilimsel araştırma yöntemi. Ankara: Nobel Yayınları

[19] Kazelskis, R. (1999). Some dimensions of mathematics anxiety: A factor analysis across instruments. Educational and Psychological Measurement, 58 (4), 623-634

[20] Kirk, J. and Miller, M. L. (1986). Reliability and validity in qualitative research. CA, Bevery Hills: Sage Publications.

[21] Le Compte, M. D. \& Goetz, J. P. (1982). Problems of reliability and validity in ethnographic research. Review of Educational Research, 52, 31-60.

[22] Ma, X. \& Xu, J. (2004). The Causal ordering of mathematics anxiety and mathematics achievement: A Longitudinal Panel Analysis. Journal of Adolescence, 27 (2), 165-179.

[23] Marzano, R., Pickering, D. \& Pollock J. (2001). Classroom instruction that works: Research-based strategies for increasing student achievement. Alexandria, VA: Association for Supervision and Curriculum Development.

[24] McDonough, A. (1992). Learning environments in 
mathematics: Exploring pupil perceptions. Conference proceedings herd at Hawkaid Conference Centre, University of Western Sydney.

[25] MEB, (2013). Talimve Terbiye Kurulu ilköğretim matematik Dersi 5-8. Sinıflar öğretim programı. Ankara

[26] Miles, M. B. \& Huberman, M. (1994). Qualitative data analysis: An expanded source book. (2 $2^{\text {nd }}$. Edition). CA: International Education and Professional Publisher, Thousand Oaks, Sage Publications.

[27] Miller, L.D. \& Mitchell, C.E. (1994). Mathematics anxiety and alternative methods of evaluation. Journal of Instructional Psychology, 21, 353-358.

[28] Norwood, K.S. (1994). The effects of instructional approach on mathematics anxiety and achievement. School Science and mathematics, 94, 248-254

[29] Oğuzkan, F. (1989). Orta dereceli okullarda ögretim: Amaç, ilke, yöntem ve teknikler. Ankara: Emel Matbaacılık.

[30] Öztürk, T. \& Güven, B. (2012). Etkili bir matematik öğrenme ortamının sahip olması gereken özelliklerine ilişkin öğretmen görüşleri. Retrieved from http://kongre.nigde.edu.tr/xufbmek/dosyalar/tam_metin/pdf/ 2410-30_05_2012-16_42_19.pdf on 21.9.2016.

[31] Patton, M. Q. (2002). Qualitative research and evaluation methods. ( $3^{\text {rd }}$. Edition). International Education and Professional Publisher. CA: Thousand Oaks, Sage Publications.

[32] Reynolds, D. (2010). Failure free education? The Past, present and future of school effectiveness and school improvement. London: Routledge.

[33] Santos-Trigo, M. (2007). Mathematical problem solving: an evolving research and practice domain. ZDM Mathematics Education, 39, 523-536.

[34] Soylu, Y. (2009). Sınıf öğretmen adaylarının matematik derslerinde öğretim yöntem ve teknikleri kullanabilme konusundaki yeterlilikleri üzerine bir çalışma. Mersin Üniversitesi Ĕ̈itim Fakültesi Dergisi, (5), 1, 1-16.

[35] Steward, C. \& Cash, W. B. (1985). Interviewing: Principles and practices. $\left(4^{\text {th }}\right.$.edition). Dubuque, IO: Brown Publication.

[36] Sullivan, P. (2011). Teaching mathematics: Using research-informed strategies. (Editor: Suzanne Mellor) Australian Education Review, no. 59, Australian Council for Educational Research, ACER Press.

[37] Şişman, M. (2006). Öğretmenliğe giriş (3.Baskl). Ankara: Pegem A Yayıncılık

[38] Tatar, E. \& Dikici, R.(2008). Matematik eğitiminde öğrenme güçlükleri. Mustafa Kemal Üniversitesi Sosyal Bilimler Enstitüsü Dergisi, 5, 9.

[39] Toluk, Z. (2003). Üçüncü uluslararası matematik ve fen araştırmas1 (TIMMS): Matematik nedir? İlköğretim online, (2), 1 s. $36-41$.

[40] Toptaş, V. (2011). Sınıf öğretmenlerinin matematik dersinde alternative ölçme ve değerlendirme yöntemlerinin kullanımı ile ilgili algıları. Ĕgitim ve Bilim.36-159.

[41] Townsend, M. A. R., Moore, D. W., Tuck, B. F. \& Wilton, K. M. (1998). Self-concept and anxiety in university students studying social science statistics within a cooperative learning structure. Educational Psychology, 18, 41-54.

[42] Umay, A. (1996). Matematik eğitimi ve ölçülmesi. Hacettepe Ünversitesi Ĕgitim Fakültesi Dergisi,(12), $145-149$.

[43] Verschaffel, L., De Corte, E., Lasure, S., Vaerenbergh, G.V., Bogaerts, H. \& Ratinckx, E., (1999). Learning to solve mathematical application problems: A Design experiment with fifth graders. Mathematical Thinking and Learning, (1), $3,195-229$

[44] Yıldırım, A. \& Șimșek, H. (2013). Sosyal bilimlerde nitel araştırma yöntemleri (13.Basım). Ankara: SeçkinYayıncılık.

[45] Yin, R. K. (1984). Case study research: Design and methods. Baverly Hills, CA: Sage Publications.

[46] URL 1: http://education.cu-portland.edu/blog/teaching-strate gies/

[47] URL2: http://www.cmu.edu/teaching

[48] Akınsola, M. K. \& Anımasahun, I. A. (2007). The effect of simulation-games environment on students achievement in and attitudes to mathematics in secondary schools. The Turkish Online Journal of Educational Technology, 6(3), 113-119.

[49] Aktepe, V., Tahiroğlu, M. \& Acer, T. (2015). Matematik öğretiminde kullanılan öğretim yöntemlerine ilişkin öğrenci görüşleri. Nevşehir Hacı Bektaş Veli Üniversitesi, Sosyal Bilimler Enstitüsü Dergisi, (4), 127-143.

[50] Alkan, H. \& Altun, M. (1998). Matematik öğretimi (Editör: Aynur Özdaş). Eskişehir: Anadolu Üniversitesi Yay. No: 591.

[51] Baş, M. (2015). The using of IWBs by primary school teacher in mathematics classrooms. International Journal of Eurasia Social Sciences 6, (21), 121-135.

[52] Güçlü, M. (2014). İlköğretim Dergisi'nin fen ve matematik ögretimi açısından değerlendirilmesi (1939-1966). Turkish Studies, 9 (7), 311-330.

[53] Tay, B. (2013). Elaboration and organization strategies used by prospective class teachers while studying social studies education textbooks. Eurasian Journal of Educational Research, 13 (51):229-252.

[54] Hung C. M., Hwang G. J. \& Huang I., A. (2012). Project-based digital storytelling approach for improving students' learning motivation, problem-solving competence and learning achievement. Educational Technology \& Society, 15 (4), 368-379.

iThis study was presented at the 3rd International Congress on Curriculum and Instruction (ICCI - 2015), which was held between 22-24 October 2015 at University of Çukurova, Turkey. 